\title{
CORPORATE GOVERNANCE REPORTING IN INDIAN BANKING COMPANIES
}

\author{
* DR. RAJU JAVALI \\ ** PROF. CHAYA BAGRECHA
}

\&

*** Ms. Rekha R Gandhi

\section{INTRODUCTION}

Corporate Governance is the set of processes, customs, policies, laws and institutions affecting the way a corporation is directed, administered or controlled. Corporate governance also includes the relationships among the many players involved (the stakeholders) and the goals for which the corporation is governed. The principal players are the shareholders, management and the board of directors. Other stakeholders include employees, suppliers, customers, banks and other lenders, regulators, the environment and the community at large.

Corporate governance is a multi-faceted subject. An important part of corporate governance deals with accountability, fiduciary duty and mechanisms of auditing and control. In this sense, corporate governance players should comply with codes to the overall good of all constituents. Another important focus is economic efficiency, both within the corporation (such as the best practice guidelines) as well as externally (national institutional frameworks). In this "economic view", the corporate governance system should be designed in such a way as to optimize results.
Corporate governance mechanisms have been an important issue of enquiry for the researchers across the world. Both theoretical models and empirical analysis have been developed in this area to explain the occurrence of different mechanisms and their usefulness in terms of improving firm performance. The Indian corporate scenario was more or less stagnant till the early 90 s but, after the liberalization of the 90 s, the position and goals of the Indian corporate sector changed considerably. Companies now know that good governance generates investor goodwill and confidence. Now there is even more reason for them to improve their governance practices. Numerous recent studies emanating from academic circles have highlighted the importance of good corporate governance in increasing market valuations and boosting the bottom line.

The importance of good Corporate Governance has been increasingly recognized for improving the firm's competitiveness, better corporate performance and better relationship with all stakeholders', because of which the Indian Corporates, have obliged to reform their principles of Governance.

This paper is an attempt to analyze the usefulness of corporate governance using reported financial information from the banking and finance sector of the NSE 100 companies.

* Reader, Institute of Management Studies, Davanagere.

* MBA(Ph.D) SRN Adarsh College, Bangalore

*** MBA, Training Co ordinator, VIMAS, Bangalore

1 Tiwary, Ojha, Arun Kumar, "Corporate Governance in India: What it Means and What it needs?", The Indian Journal of Commerce, New Delhi, Oct-Dec,1998, p.154. 


\section{KEY ISSUES IN CORPORATE GOVERNANCE}

Corporate Governance is a means to an end, the end being long term shareholder, and more importantly, stakeholder value. Thus, all authorities on the subject are for recognizing the need for good governance practices to achieve the end for which corporates are formed. They identify some governance issues being crucial and critical to achieve these objectives. These are:

a. Board Of Directors who are the mind and soul of the organization

b. Audit, which is a confidence building exercise

c. Remuneration Committee that motivates the people at the helm of affairs

d. Shareholders Grievance Committee to ensure satisfied investors

e. General Body Meeting which acts as a platform to provide right communication at the right time to the stakeholders

f. Disclosures of Related Parties to ensure transparency and rationality in all the dealings

g. Means of Communication that helps in timing and quantum of information

h. General Shareholder Information adds corporate value

The corporate responsibility begins with the directors who are the mind and soul of the organization. The Board is expected to act as a conscience-keeper of the corporate vision and mission, and devise the right type of systems for organizational effectiveness and satisfaction of stakeholders The disclosure / transparency issue of Corporate Governance eventually centers around the proper accounting standards, their practices and issues, as the application of accounting standards give a lot of confidence to the corporate management and the disclosure would be more effective and ensure good Corporate Governance. Thus, the study of practices of accounting and auditing standards is an important and relevant issue of good Corporate Governance in the present environment, as the standards are viewed as a technical response to call for better financial accounting and reporting; or as a reflection of a society's changing expectations of corporate behavior and a vehicle in social and political monitoring and control of the enterprise ${ }^{2}$.

\section{CORPORATE GOVERNANCE IN BANKS}

Banks are a critical component of the economy as they are the providers of finance to the industry and trade. Their importance can also be understood by the fact that they are the most regulated, at the same time most protected.

Banks are corporations themselves. It is therefore very important that banks have strong Corporate Governance practices. Corporate Governance affects banks' valuation and their cost of capital. Corporate Governance of banks thereby affects the cost of capital of the firms and households they lend to. Corporate Governance affects banks' performance, i.e., costs of financial intermediation, and thereby the cost of capital of the firms and households they lend to. Corporate Governance affects banks' risk-taking and risks of financial crises, both for individual banks and for countries' overall banking systems. ${ }^{3}$

2 R.I.Ticker, "Corporate Responsibility, Institutional Governance and the Roles of Accounting Standards" in Michael Bromwich and Anthony G. Hopwood (Eds.), Accounting Standards Setting, An Intemational Perspective, Pitman Books Ltd., London, 1883, p.27., Cited in Lele RK, Jawahar Lal, "Accounting Theory", Himalaya Publishing House, New Delhi, 96,p.56.

3 Stijn Claessens, Senior Adviser, Operations and Policy Department, Financial Sector Vice-Presidency, World Bank for the Consultative OECDMorld Bank Meeting on Corporate Governance, December 6-7, Hanoi, Vietnam. 
Bank behavior influences economic outcomes. Banks mobilize and allocate society's savings. Especially in developing countries, banks can be very important source of external financing for firms. Banks exert Corporate Governance over firms, especially small firms that have no direct access to financial markets. Banks' Corporate Governance gets reflected in Corporate Governance of firms they lend to. Thus, governance of banks is crucial for growth and development of the economy.

The banking operations are governed by Basel II accord. Basel II is an International Business Standard that requires financial institutions to maintain enough cash reserves to cover risks incurred by operations. The Basel accords are a series of recommendations on banking laws and regulations issued by the Basel Committee on Banking Supervision (BCBS).

Basel Il uses a "three pillars" concept -

(1) minimum capital requirements (addressing risk)

(2) supervisory review and

(3) market discipline - to promote greater stability in the financial system.

\section{LITERATURE REVIEW}

Various research studies have highlighted the importance of banks in the economy. They are critically important for industrial expansion, the Corporate Governance of firms, and capital allocation (Kaplan and Minton, 1992, Levine 1997, 2003). When banks efficiently mobilize and allocate funds, this lowers the cost of capital to firms, boosts capital formation and stimulates productivity growth (Levine 2003). Thus the functioning of banks has ramifications for the operations of firms and the prosperity of nations. ${ }^{4}$

According to Levine (2003) banks' corporate governance need to be studied separately due to the following special features of banks. First banks are generally more opaque than non financial firms. ${ }^{5}$ Second, banks are frequently very heavily regulated. Levine also added that because of the importance of banks in the economy, because of the opacity of the bank assets and activities, and because banks are a ready source of fiscal revenue, governments impose an elaborate array of regulations on banks. Also, to improve corporate governance of financial intermediaries, especially banking companies, policy makers must seek to enhance the ability and incentives of creditors and other market participants to monitors of banks (Caprio and Levine, 2002)

Numerous recent studies emanating from academic circles show that good Corporate Governance increases valuations and boosts the bottom line.

For example, a recent study by Gompers, Ishii, and Metrick (2003) shows that companies with strong shareholder rights yielded annual returns that were 8.5 percent greater than those with weak rights. Specifically, an investment of $\$ 1$ in the democratic portfolio on September 1, 1990, would have grown to $\$ 7.07$ by December 31,1999 , or 23.3 percent annually. In contrast, companies in the dictatorship portfolio would have grown to only $\$ 3.39$, or 14 percent annually.

4 for a review of the impact of banks on the economy, see Levine $(1997,2004)$

5 A more comprehensive analysis on corporate governance of the banking companies in developing economies has been done in the study of Arun and Turner, 2002. 
Theoretical models by La Porta, Lopez-de-Silanes, Shleifer and Vishny (2002) and Shleifer and Wolfenzon (2002) predict that investors pay more because they recognize that, with better legal protection, more of the firm's profits would come back to them as interest or dividends as opposed to being expropriated by the entrepreneur who controls the firm.

Overall, the conclusion seems to be that corporate governance is still in a very nascent stage in the Indian industry. The decision and policy making is still taken mostly as a routine matter. Among the institutional investors also, it seems that the Foreign Institutional Investors are the most consistent in stock picking whereas the performances of the domestic institutional investors are sporadic and volatile at best. This is also serious shortcoming on the part of the capital market, not being able to enforce better governance on the part of the directors or performance on the part of the managers.

Arun and Turner (2002) discussed the theoretical analysis of Corporate Governance of banking in developing economies, in general and Corporate Governance of banking sector specially public sector banks in India, in particular. The researchers argued that banks have a unique contractual nature implying that the interests of other stakeholders appear more important to it than in the case of non-banking organisations. Their observation is that Corporate Governance issues have not received much attention in the first generation of financial sector reforms after 1991. In India, the issues have become important in the second decade of reforms.
There is an urgent need to review the size and composition of the Public Sector Bank boards to make them effective instruments of Corporate Governance. The study of Arun and Turner (2003) is another good theoretical discussion of the Corporate Governance of banking institutions in developing economies. They suggested that the Corporate Governance of banks in developing economies is severely affected by political considerations ${ }^{6}$.

Das and Gupta (2004) examined the issues of Corporate Governance in the Indian banking system. Using data on banking systems, 27 public sector banks for the period 1996-2003, the findings reveal that CEOs of poorly performing banks are likely to face higher turnover than CEOs of well performing ones ${ }^{7}$. The researchers pointed out that along this dimension, Corporate Governance is effective. However, these findings do not imply that Corporate Governance in Indian banks is perfect.

\section{METHODOLOGY}

The current study focuses on the banking sector in India. The study covers 14 banking and finance companies from the NSE100 companies. Annual reports for the year 2007-08 were collected from company websites and mail.

This study tackles five basic questions:

$\checkmark$ First, whether banks established prior to 1975 disclose more information than those established after 1975.

- Arun, T.G and Turner, J. D., "Corporate Governance of Banks in Developing Economics: Concepts and Issues", Corporate Governance: An International Review, Vol.12(3), 2003, 371-377.

7 Das, A, and Ghosh, S., "Corporate Governance of Banking System, An Empirical Investigation", Economic and Political Weekly, March 20, 2004, 1263-1266. 
$\checkmark$ Second, whether the banks with higher profitability disclose more than those with lesser profits.

$\checkmark$ Third, whether banks with higher governance scores fare better than the sensex.

$\checkmark$ Fourth, whether banks with high governance scores have high profitability than industry average.

$\checkmark$ Fifth, whether banks with higher value of total assets have higher levels of disclosure.

\section{CONSTRUCTION OF CORPORATE GOVERNANCE SCORE}

Corporate governance score is constructed for each bank on a scale of 57 . This list of items is spread across the important issues of Corporate Governance. This approach is adopted in the study as other researchers used this approach. (Wallace, 1987; Cooke, 1991 and 1992; Karim, 1995; Hossain et al., 1994; Ahmed and Nicholls, 1994; and Hossain, 1999, 2003).

After browsing through the annual reports and an indepth study of the Corporate Governance report section of the same, the presence or absence of each and every item in the list was checked. The bank scored 1 if the said item was present and 0 if the said item was not present. The score for the bank was the total derived by adding all the $1 \mathrm{~s}$. Hence, it is an additive model. All the items are considered equally important and the maximum that a bank can score is 57 .

Averages and correlation between various issues of governance and governance score were found out.
The companies included in the study are:

AXIS Bank Ltd. IDFC

Bank of Baroda Kotak Mahindra Bank Ltd.

Bank Of India Punjab National Bank

HDFC Reliance Capital Ltd.

HDFC Bank Ltd. State Bank of India

ICICl Bank Ltd. Union Bank of India

$|\mathrm{DB}|$

\section{FINDINGS}

The important findings of the study are summarized here.

1. The disclosure level of banks is very high indicating a high level of compliance.

2. Banks incorporated after 1991 have a higher Corporate Governance score (48) than those incorporated before 1991(44.7).

3. Bank of Baroda has the highest Governance score of 52 among those established before 1991.

4. $\mathrm{IClCl}$ bank has the highest Governance score of 52 among those established after 1991.

5. There seems to be a low positive relationship between Year of Establishment and Governance score (0.170882). This indicates that newer banks have higher scores, but it is not a very strong indication.

6. All the banks have disclosed all the required information (100\%) about board of directors.

7. Not many companies have disclosed about postal ballots conducted (or not conducted).

8. Changes in accounting treatment have not found a mention in the Corporate Governance report.

9. Detailed profiles of directors and chairman appointed during the year are not disclosed by almost $50 \%$ of the companies. 
10. None of the banks except Bank of Baroda and $\mathrm{ICICI}$ have sent copies of half yearly report to their shareholders.

11. No information is provided about presentations made to institutional investors by most of the banks.

12. Information about senior management structure and background about the senior managers is not provided by $77 \%$ of the companies.

13. Not a single bank has provided CEO's contact address/id in its reports.

14. Moderately positive correlation between Corporate Governance score and total assets $(0.439997)$ indicates bigger banks reveal more than smaller banks. But, there is high correlation (0.59) between Corporate Governance score and total assets when banks with assets higher than 150000 crores were studied.

15. There seems to be a negative correlation between Corporate Governance score and capital adequacy ratio $(-0.33044)$

16. There is very low negative correlation $(-0.11)$ between earning per share and Corporate Governance score which indicates that there may be no relationship between performance of the banks and their disclosure levels.

\section{LIMITATIONS:}

1. The score only indicates the presence or absence of a particular issue in the Corporate Governance report of the bank. What it does not indicate is whether the count is favorable or not, e.g., fines paid, contingent liability, pending complaints, etc.
2. Good Corporate Governance and high performance of the company do not occur in the same period, that is, performance has a lag effect of one to three years, but that is ignored. It is assumed that Governance and Performance coexist on the timeline.

3. Number of board meetings and presence of directors has been identified, but what could not be understood and appreciated was the outcome of those meetings in terms of positive impact on the future of the bank.

4. Single time period is not sufficient to bring out any conclusive evidence about the relationship between bank characteristics and governance.

\section{CONCLUSION}

The efforts of the government and SEBI in making corporate governance a part of the Annual report has found $100 \%$ success. Banks, big and small, old and new, profitable and not so profitable, are disclosing both mandatory and non-mandatory issues to a very large extent. What remains to be done is that it does not coritinue to be reported only in letter but also in spirit. This will go a long way in building the confidence levels of stakeholders.

\section{REFERENCES}

Arun, T.G and Turner, J. D., "Corporate Governance of Banking Institutions in Developing Economies: The Indian Experience", Paper presented in the conference on 'Finance and Development' organised by IDPM, The University of Manchester, 2000.

Arun, T.G and Turner, J. D., "Corporate Governance of Banks in Developing Economics: Concepts and Issues", Corporate Governance: An International Review, Vol.12(3), 2003, 371-377. 
Confederation of Indian Industry, CII., " Desirable Corporate Governance: A Code", 1998.

Das, A, and Ghosh, S., "Corporate Governance of Banking System, An Empirical Investigation",

Economic and Political Weekly, March 20, 2004, 1263-1266.

Goswami, O., "The State of Corporate Governance in India", in A comparative Analysis of corporate governance in South Asia (eds) Farooq Sobhan and Wendy Werner, Bangladesh Enterprises Institute, Dhaka, 2003, 127-163.

Hossain, M. Tan, L. M., and Adams, M., "Voluntary Disclosure in an Emerging Capital Market: Some Empirical Evidence from Companies Listed on the Kuala Lumpur Stock Exchange", The International Journal of Accounting, Vol. 29, 1994, 334-351.

Hossain, M.A., "Disclosure of Financial Information in Developing Countries: A Comparative Study of Non-financial Companies in India,
Pakistan and Bangladesh", Unpublished PhD Dissertation, The University of Manchester, 1999.

Levine, R., "Financial Development and Economic Growth: Views and Agenda", Journal of Economic Literature, Vol.35, 1997, 688-726.

Levine, R., "Corporate Governance of Banks:A Concise Discussion of Concepts and Evidence", Discussion Paper No.3, Globle Corporate Governance Forum, University of Minnesota, 2003. Report of the Committee on Banking Sector Reforms, Narasimham Committee Report II, Ministry of Finance, Government of India, New Delhi, 1998.

Shleifer, A. and Vishny, R., "Large Shareholders and Corporate Control", Journal of Political Economy, Vol.94, 1986, 461-88

Shleifer, A. and Vishny, R., "A Survey of Corporate Governance", Journal of Finance, Vol.52, 1997,737783. 